\title{
Pengaruh Penggunaan Brand Endorser Arief Muhammad Terhadap Brand Awareness Tokopedia
}

\author{
Clemens, Wulan Purnama Sari \\ Clemenssaleppa@gmail.com,Wulanp@fikom.untar.ac.id
}

Fakultas Ilmu Komunikasi Universitas Tarumanagara

\begin{abstract}
The development of existing technology now leads to new forms of promotion. One of them is Brand Endorser. The purpose of this study is to determine / describe the influence of the use of the use of brand endorser (Arief Muhammad) in the \#MulaiAjaDulu advertisement to influence brand awareness of TOKOPEDIA. awareness is examined using AIDA theory (Attention, Interest, Desire, Action). This research is a quantitative research using survey method. The population of this study is all people who have watched the \#mulaiaja advertisement first, Arief Muhammad. While the sample was chosen at the age of 17 - 35. The results of the data show that there is an influence of the use of brand endorsers on brand awareness. The mean results obtained indicate that the expertise or expertise of brand endorsers is a factor in the attention points of brand awareness gained. The results of this study indicate that 1) there is an influence between Brand Endorser on Brand Awareness. Although the influence exerted was not great, 2) the expertise of Arief Muhammad as an endorser, gave a great attention effect to TOKOPEDIA, the expertise possessed by Arief Muhammad was the key to Arief Muhammad's success in contributing Attention to TOKOPEDIA and 3) The use of Arief Muhammad as endorser, does not directly create actions to use TOKOPEDIA.
\end{abstract}

Keywords: attention, Brand awareness, brand Endorser.

Abstrak

Perkembangan teknologi yang ada sekarang ini membawa kepada bentuk - bentuk promosi yang baru. Salah satunya adalah Brand Endorser. Tujuan dari penelitian ini adalah untuk mengetahui/mendeskripsikan pengaruh dari penggunaan penggunaan brand endorser (Arief Muhammad) di dalam iklan \#MulaiAjaDulu berpengaruh terhadap brand awareness dari TOKOPEDIA.Brand endorser dikaji dengan menggunakan teori TEARS (Trustworthiness, Expertise, Attraction, Respect, Similarity) dan brand awareness dikaji menggunakan teori AIDA(Attention, Interest, Desire, Action). Penelitian ini adalah penelitian kuantitatif dengan menggunakan metode survei. Populasi dari penelitian ini adalah seluruh orang yang telah menonton iklan \#mulaiaja dulu versi Arief Muhammad. Sedangkan sampel dipilih didalam umur 17 - 35. Hasil data menunjukkan bahwa terdapat pengaruh dari penggunaan brand endorser terhadap brand awareness. Dari hasil mean yang didapat menunjukkan bahwa expertise atau keahlian dari brand endorser menjadi faktor terhadap poin attention dari brand awareness yang didapat. Dari data penelitian ditemukan bahwa 1) terdapat pengaruh antara Brand Endorser terhadap Brand Awareness. Walau pengaruh yang diberikan tidak besar, 2) keahlian dari Arief Muhammad sebagai endorser, memberi dampak attention yang besar bagi TOKOPEDIA, expertise yang dimiliki oleh Arief Muhammad menjadi kunci dari keberhasilan Arief Muhammad didalam menyumbang Attention bagi TOKOPEDIA dan 3) Penggunaan Arief Muhammad sebagai endorser, tidak secara langsung menciptakan action untuk menggunakan TOKOPEDIA.

Kata Kunci: Brand Endorser, Brand Awareness, Expertise, Attention 


\section{Pendahuluan}

Di era modern seperti saat ini, teknologi menjadi semakin maju dan canggih, baik pada bidang komunikasi maupun informasi. Kemajuan teknologi ini ditandai dengan kemunculannya internet. Dengan munculnya internet, informasi menjadi mudah tersebar secara cepat dan luas sehingga masyarakat Indonesia bisa dengan mudahnya mengakses dan mendapatkan informasi dari berbagai negara lain. Dengan demikian, hal ini mendorong budaya luar untuk masuk ke Indonesia. (Budiman, Loisa, Pandrianto, 2018)

Berkembangnya internet, menimbulkan sebuah sistem belanja baru yang dikenal dengan nama E-Commerce. E-Commerce adalah suatu cara belanja baru yang dilakukan secara daring, sehingga dapat menciptakan keefisiensian, dibanding belanja konvensional. Seperti media sosial, E-Commerce memiliki beberapa platform dengan tampilan, cara promosi dan bahkan fitur - fitur berbelanja yang berbeda-beda, seperti Tokopedia, Shopee, Lazada, Jd.Id, Bli-Bli, Zalora, dan lain-lain. Bertumbuhnya industri E-Commerce tentu disebabkan oleh peminat belanja daring yang semakin banyak. Hal ini dapat dilihat dari statistik yang dirilis oleh Statis pada tahun 2017 yang mengatakan bahwa sementara pembeli digital Indonesia diperkirakan mencapai 31,6 juta pembeli pada 2018 , dengan penetrasi sekitar $11,8 \%$ dari total populasi. Jumlah tersebut diproyeksikan akan meningkat menjadi 43,9 juta pembeli pada 2022 dengan penetrasi $15,7 \%$ dari jumlah penduduk Indonesia. Dari data yang dikumpulkan oleh Iprice dari semua platform E-Commerce yang berbeda - beda, Tokopedia telah menjadi market leader, sejak triwulan IV 2018.

Keberhasilan TOKOPEDIA didalam menjadi market leader tentu tidak lepas dari kegiatan komunikasi pemasaran yang baik. Kotler \& Keller (2012) mengatakan bahwa komunikasi pemasaran adalah sarana yang digunakan perusahaan dalam upaya untuk menginformasikan, membujuk, dan mengingatkan konsumen baik secara langsung maupun tidak langsung tentang produk dan merek yang mereka jual. Salah satu kegiatan komunikasi pemasaran adalah dengan menggunakan brand endorser, Ini merupakan cara untuk meningkatkan brand awareness dengan cara menggunakan jasa promosi dari seorang tokoh atau figur yang dikenal oleh publik karena karyanya.

Menurut Shimp (2003), endorser adalah pendukung iklan atau juga yang dikenal sebagai bintang iklan yang mendukung produk yang diiklankan. Dalam konteks ini, TOKOPEDIA telah merilis sebuah iklan promosi dengan judul \#MulaiAjaDulu. Video promosi ini dirilis oleh TOKOPEDIA dengan format soft selling yang menggunakan jasa beberapa brand endorser seperti, Arief Muhammad, Reza Oktovian, Ria Ricis.

Di dalam penelitian ini, penulis menggunakan iklan versi brand endorser Arief Muhammad. Pemilihan Arief Muhammad, didasarkan pada aktivitas ROI atau Return Of Investment Arief Muhammad yang memiliki kuantitas dan kualitas yang baik, sehingga dapat diketahui bahwa sebagian besar dari kalangan masyarakat mengenal Arief Muhammad. Oleh sebab ini, maka ditemukan sebuah rumusan masalah yaitu "Apakah terdapat pengaruh antara penggunaan brand endorser Arief Muhammad terhadap brand awareness TOKOPEDIA didalam iklan \#mulaiajadulu", dengan tujuan mengetahui dan mengukur efektivitas pengaruh penggunaan brand endorser Arief Muhammad di dalam iklan \#MulaiAjaDulu terhadap brand awareness dari TOKOPEDIA.Untuk mengkaji penelitian ini digunakan Teori TEARS dari Shimp (2003) dan AIDA dari Kotler dan Keller (2012). 


\section{Metode Penelitian}

Penelitian ini menggunakan pendekatan kuantitatif. Pendekatan kuantitatif adalah metode penelitian yang berlandaskan pada pemikiran positivisme, pendekatan kuantitatif adalah lawan dari eksperimen dimana kondisi alami dari penelitian itulah yang diteliti. Peneliti adalah instrumen kunci, pengambilan sampel sebagai sumber data dilakukan secara purposive dan snowball (Sugiyono, 2011). Metode yang digunakan adalah metode survei dengan menggunakan angket sebagai alat ukur nya. Penelitian dilakukan dengan populasi "semua orang yang pernah menonton iklan \#mulaiajadulu versi Arief Muhammad, dan Sampel yang diambil adalah berusia 1725 tahun untuk kategori usia remaja akhir dan 26-35 tahun untuk kategori usia dewasa awal,serta berdomisili di Jabodetabek. Penelitian dilakukan dengan pre test dan post test. Pre test dilakukan dengan terlebih dahulu menyebar kuesioner terhadap 30 responden. Setelah itu baru dilakukan post test terhadap 135 responden. Data - data Responden yang telah diperoleh melalui Google Form dan untuk menguji keabsahan data digunakan 3 jenis pengujian, yaitu uji Validitas, Reliabilitas serta Uji Normalitas. Selanjutnya untuk menganalisis data, menggunakan uji hipotesis (Uji T \& Uji F), Analisis Regresi, Koefisien Korelasi dan Koefisien Determinasi.

\section{Hasil Penemuan dan Diskusi}

Tokopedia adalah perusahaan teknologi Indonesia yang mempunyai sebuah tujuan untuk mencapai pemerataan ekonomi secara digital. Didirikan pada tahun 2009, kini perusahaan Tokopedia telah berkembang menjadi sebuah perusahaan unicorn. Unicorn adalah perusahaan yang telah memiliki kapitalisasi lebih dari 1 miliar dollar.

Hingga saat ini, Tokopedia menjadi marketplace yang paling banyak dikunjungi oleh masyarakat Indonesia. Sejak diluncurkan, layanan dasar Tokopedia dapat digunakan oleh semua orang secara gratis. Dengan visi "Membangun sebuah ekosistem dimana siapa pun bisa memulai dan menemukan apapun",Tokopedia berhasil menguatkan keberadaan jutaan pedagang dan konsumen untuk berpartisipasi dalam masa depan perekonomian Indonesia. Tokopedia secara konsisten memberikan support kepada masyarakat yang memiliki usaha untuk mengembangkan usaha mereka dengan memasarkan barang atau produk mereka dengan cara daring/online.

Tokopedia resmi dikenalkan kepada masyarakat tepat pada tanggal 17 Agustus 2009, tepat dengan hari kemerdekaan Indonesia. Tokopedia dikembangkan oleh William Tanuwijaya dan Leontinus Alpha Edison dimulai sejak tanggal 6 Februari 2009. Sejak resmi diluncurkan, PT Tokopedia merupakan salah satu perusahaan berbasis internet yang memiliki perkembangan yang cepat. Perkembangan yang terus dibuat oleh Tokopedia membuat Tokopedia menempati urutan pertama di dalam kompetisi dengan e-commerce lainnya.

Penelitian dilakukan dengan metode pre test dan post test. Metode pre test dilakukan dengan cara menyebar kuesioner terlebih dahulu kepada 30 responden. Penyebaran kuesioner untuk pre - test dilakukan melalui Google Form. Hasil yang didapatkan, bertujuan untuk mengetahui validitas dan reliabilitas dari penelitian ini. Berdasarkan hasil uji validitas yang dilakukan, ditemukan bahwa 20 butir pertanyaan Variabel X memiliki nilai > 0,300 sehingga dinyatakan valid. Demikian pun pada 14 pertanyaan dari Variabel Y, semua memiliki nilai > 0,300 sehingga juga dinyatakan valid. Setelah dilakukan uji validitas, maka dilanjutkan untuk mengetahui reliabilitas 
dari data yang didapatkan. Berdasarkan uji reliabilitas maka didapatkan hasil 0,950 untuk Variabel X dan 0,910 untuk variabel Y, dengan hasil kedua variabel memiliki nilai diatas 0,7 maka penelitian ini dinyatakan reliabel.

Setelah melakukan tahapan pre test, maka dilanjutkan dengan tahapan post test. Penelitian memiliki populasi yaitu orang - orang yang sudah pernah menonton iklan \#mulaiajadulu versi Arief Muhammad

Kuesioner kembali disebarkan kepada 135 responden, melalui Google Forms. Berdasarkan hasil respon yang telah di tabulasi maka diketahui bahwa tanggapan pada variabel X berdominasi kepada Setuju dan tanggapan pada variabel Y. Dari tabulasi data, penulis melakukan uji regresi linier dan mendapatkan hasil sebagai berikut.

\section{Analisis Regresi Linier Sederhana}

Coefficients $^{\mathrm{a}}$

\begin{tabular}{|rl|r|r|r|r|r|}
\hline \multicolumn{2}{|l|}{ Model } & \multicolumn{2}{|c|}{ Unstandardized Coefficients } & \multicolumn{1}{c|}{$\begin{array}{c}\text { Standardized } \\
\text { Coefficients }\end{array}$} & \multirow{2}{*}{ Sig. } \\
\cline { 3 - 5 } & \multicolumn{1}{|c|}{$\mathrm{B}$} & Std. Error & \multicolumn{1}{c|}{ Beta } & & \\
\hline \multirow{2}{*}{1} & (Constant) & 15,854 & 6,379 & & 2,485 &, 020 \\
& Brand Endorser &, 348 &, 105 &, 545 & 3,318 &, 003 \\
\hline
\end{tabular}

a. Dependent Variable: Brand Awareness

Sumber: Pengolahan Data SPSS 22

Berdasarkan hasil analisis data diatas diketahui bahwa nilai $\mathrm{t}=3,318$ dan tingkat signifikan $=0,003<0,05$. Karena nilai $\mathrm{r}<0,005$ maka Ho ditolak dan Ha diterima yang berarti terdapat pengaruh Brand Endorser terhadap Brand Awareness: AIDA TOKOPEDIA. Terdapat pengaruh yang signifikan antara Brand Endorser terhadap Brand Awareness: AIDA karena tingkat signifikansi lebih kecil dari 0,05.

Berdasarkan tabel 4.34 diketahui bahwa nilai parameter dari regresi linear sederhana dengan hubungan $\mathrm{X}$ mempengaruhi $\mathrm{Y}$ adalah:

$$
\begin{aligned}
& a=15,854 \\
& b=0,348
\end{aligned}
$$

Dengan demikian didapatkan nilai regresi linear sederhana sebesar

$\mathrm{Y}=\mathbf{1 5}, \mathbf{8 5 4 + 0 , 3 4 8 X}$

Berdasarkan persamaan diatas, maka dapat diartikan bahwa nilai sebesar 15,854 menyatakan sebagai konstanta dari fungsi regresi yang menunjukan bahwa jika ada kenaikan pada variabel X (Brand Endorser), maka pada variable $\mathrm{Y}$ (Brand Awareness: AIDA) akan mencapai 28,234. Setia pada penambahan angka atau perubahan pada variabel X (Brand Endorser), maka variable Y (Brand Awareness: AIDA) akan mengalami peningkatan sebesar 0,348..

Lalu penulis mencari hasil mean dari tiap dimensi untuk menentukan dimensi mana yang menjadi pengaruh yang paling besar dan apa dimensi yang memiliki dampak paling besar dari pengaruh tersebut.

\begin{tabular}{|c|c|c|c|c|}
\hline & $\mathrm{N}$ & Minimum & Maximum & Mean \\
\hline Attraction & 6 & 2,2 & 3,21 & 2,80 \\
\hline Expertise & 4 & 3,13 & 3,26 & 3,18 \\
\hline Trustworthiness & 4 & 2,7 & 3,25 & 3,06 \\
\hline Respect & 4 & 3,04 & 3,15 & 3,11 \\
\hline Similarity & 2 & 2,97 & 3,07 & 3,02 \\
\hline
\end{tabular}

Tabel 1. Hasil Mean Variabel X 
Clemens, Wulan Purnama Sari: Pengaruh Penggunaan Brand Endorser Arief Muhammad Terhadap Brand Awareness Tokopedia

Tabel 2. Hasil Mean Variabel Y

\begin{tabular}{|c|c|c|c|c|}
\hline & $\mathrm{N}$ & Minimum & Maximum & Mean \\
\hline Attention & 4 & 3,04 & 3,16 & 3,10 \\
\hline Interest & 2 & 2,41 & 2,57 & 2,49 \\
\hline Desire & 4 & 2,48 & 3,21 & 2,73 \\
\hline Action & 4 & 2,67 & 2,9 & 2,57 \\
\hline
\end{tabular}

Maka berdasarkan hasil pengolahan data diatas, dapat disimpulkan bahwa Brand Endorser memiliki pengaruh terhadap Brand Awareness. Pengaruh yang ditimbulkan berasal dari dimensi Expertise dari Arief Muhammad. Hal ini terlihat dari nilai mean yang paling besar dibandingkan dengan dimensi lain. Sedangkan pada Variabel Brand Awareness hasil nilai mean terbesar terdapat pada dimensi Attention. Maka dapat disimpulkan bahwa faktor expertise dari Arief Muhammad memiliki pengaruh paling besar terhadap Attention dari Tokopedia. Dengan menggunakan Arief Muhammad sebagai Brand Endorser maka Tokopedia dapat memiliki peningkatan perhatian kepada brand.

Dalam penelitian ini terbukti bahwa Arief Muhammad diakui sebagai Endorser yang memiliki Keahlian / Expertise. Hal ini dibuktikan dari nilai mean dimensi expertise yang tertinggi dari dimensi lainnya. Keahlian dari Arief Muhammad ini lah yang menjadi faktor dari terbentuknya attention terhadap Tokopedia. Salah satu keahlian dari Arief Muhammad adalah adalah cara menjual yang tidak eksplisit. Cara menjual dengan tidak eksplisit adalah suatu cara promosi dengan memasukkan materi iklan di dalam konten yang dibuat. Ini merupakan salah satu keahlian dari Arief Muhammad. Sebagai contoh, di dalam iklan \#mulaiajadulu Arief tidak menyebutkan untuk menggunakan Tokopedia, melainkan hanya berisi perjalanan karir Arief Muhammad yang memiliki makna bahwa ia memulai dari hal yang kecil. Hal ini selaras dengan isi pesan dari TOKOPEDIA untuk mulai berbisnis di Tokopedia. Contoh lain nya adalah, di dalam video yang berjudul "Make Over supir jadi sultan". Video ini berisi konten yang bercerita tentang Arief Muhammad mendandani supir nya hingga terlihat baik, namun didalamnya ia mendandani supir nya dengan menggunakan shampo Romano. Inilah yang merupakan kemampuan dari Arief Muhammad.

Hasil temuan dari Variabel Y adalah didapati nilai mean dari dimensi - dimensi variabel Y yang tertinggi adalah Attention. Hal ini menunjukkan bahwa Tokopedia memiliki brand awareness yang tinggi di tingkat attention. Hal ini berarti Tokopedia berhasil menarik perhatian yang lebih dibandingkan Ecommerce lainnya. Hal ini terlihat dari bagaimana Tokopedia masih menjadi E-commerce nomor 1 di Indonesia. Tokopedia telah menjadi market leader, sejak triwulan IV 2018, dengan dibayangi oleh Bukalapak. Tokopedia mendapatkan angka 168 juta pengunjung. Jumlah tersebut meningkat sebesar $9,35 \%$ dari triwulan sebelumnya dan melonjak $45 \%$ dari triwulan yang sama tahun sebelumnya. Attention ini didapat melalui penggunaan brand endorser, Arief Muhammad di dalam iklan dari TOKOPEDIA. 


\section{Simpulan}

Berdasarkan hasil pembahasan maka dapat disimpulkan bahwa, pertama, terdapat pengaruh antara Brand Endorser terhadap Brand Awareness. Kedua, keahlian dari Arief Muhammad sebagai endorser, memberi dampak attention yang besar bagi Tokopedia, expertise yang dimiliki oleh Arief Muhammad menjadi kunci dari keberhasilan Arief Muhammad didalam menyumbang attention bagi Tokopedia. Dan simpulan yang ketiga adalah penggunaan Arief Muhammad sebagai endorser, tidak secara langsung menciptakan action untuk menggunakan TOKOPEDIA, namun berhasil menarik perhatian atau attention dari responden.

\section{Ucapan Terima Kasih}

Puji dan syukur kepada Tuhan yang Maha Esa atas segala berkat dan rahmat karunia-Nya sehingga peneliti dapat melaksanakan kegiatan penelitian dan menyelesaikan penulisan jurnal ini. Penyusunan jurnal ini dapat terlaksana karena bantuan dan dukungan dari banyak pihak. Oleh karena itu, peneliti ingin menyampaikan rasa terima kasih yang sebesar-besarnya kepada semua pihak yang ikut terlibat dan telah membantu peneliti selama proses penelitian ini berlangsung, yaitu kedua orang tua, sahabat serta teman satu bimbingan dan seluruh responden yang telah bersedia mengambil bagian di dalam penelitian ini.

\section{Daftar Pustaka}

A, Shimp,Terence (2003). Periklanan Promosi \& Aspek Tambahan Komunikasi Pemasaran.Terpadu, Jilid I ( edisi 5), Jakarta: Erlangga.

Budiman, Vionita., Loisa, Riris., \& Pandrianto, Nigar. (2018). Peran Brand Ambassador Pada Iklan Dalam Membangun Brand Awareness (Studi Kasus Iklan Youtube LG G7 Thinq BTS). Prologia, Vol 2, No. 2. https://journal.untar.ac.id/index.php/prologia/article/view/3743

Kotler, Philip \& Keller, Kevin Lane. (2012). Manajemen Pemasaran. Edisi 12. Jakarta: Erlangga

Sugiyono. (2011). Metode Penelitian Kuantitatif, Kualitatif dan R\&D. Bandung: Afabeta

https://tokopedia 